Ecclesia. Studia z Dziejów Wielkopolski t. 12 (2017)

doi: 10.14746/e.2017.12.1

\title{
KATERINY ZISOPULU-BLEJA
}

Muzeum Archeologiczne w Poznaniu

\section{„Bądź pozdrowion Krzyżu Pana Wszechmocnego"1. Kafel z badań archeologicznych przy ul. Za Bramką w Poznaniu}

Wśród licznych zabytków odkrytych podczas badań archeologicznych związanych z budową parkingu przy ul. Za Bramką w Poznaniu ${ }^{2}$ znajduje się duży zbiór kafli ${ }^{3}$. Na szczególną uwagę zasługuje kafel płytowy z przedstawieniem Grupy Ukrzyżowania (fot. 1), który wydobyto z dawnej fosy miejskiej. Miejsce znalezienia i ślady sadzy na wewnętrznej powierzchni wskazują, że jest on wyrzuconym destruktem pieca. Charakter kafli jako źródła jest złożony, pod względem wykonania były one wytworem rzemiosła garncarskiego. Dekoracja natomiast zmieniała się zgodnie z aktualnie panującymi trendami i stylami zdobniczymi. W przypadku omawianego zabytku miejsce znalezienia uniemożliwia odwołanie się do szerszego kontekstu archeologicznego, stąd datowanie może być oparte przede wszystkim na analizie stylistycznej ornamentu, co z kolei nie zawsze jest dostatecznie precyzyjne ${ }^{4}$.

Kafel zwraca uwagę odbiegającą od przeciętnej wielkością, wymiary prostokątnej wydłużonej płytki wynoszą: $21,2 \times 39 \mathrm{~cm}$. Został on wykona-

${ }^{1}$ Tekst pieśni pasyjnej z 2 połowy XV wieku, która znajduje się w zachowanym fragmencie bernardyńskiego śpiewnika z Kobylina - zbiory Biblioteki Raczyńskich w Poznaniu. G. Trościński, Pieśń o Krzyżu i jej nieznany późnośredniowieczny przekaz: z zagadnień polskojęzycznego zasobu literackich pozdrowień Krzyża, „Pamiętnik Literacki” 106/1 (2015), s. 31.

${ }^{2}$ Badania, które trwały od 26.06.2014-31.03.201 r. prowadziło konsorcjum firm: Pracownia Archeologiczno-Konserwatorska SZPILA Jakub Affelski, MIGNA Magdalena Ignaczak, PHU ANWIT Antoni Smoliński, pracami kierował Krzysztof Karasiewicz. Serdecznie dziękuję za udostępnienie kafla do badań.

${ }^{3} \mathrm{~K}$. Zisopulu-Bleja, Kafle piecowe (XV-XVIII w.), odkryte $w$ trakcie prac archeologicznych w Poznaniu przy ul. Za Bramka (stan. 10, AZP 52-28/157), [w:] Opracowanie wyników archeologicznych badań ratowniczych, prowadzonych w latach 2014-2015, na stanowisku Poznań, Stare Miasto, st. 10, ul. Za Bramka, nr AZP: 52-28/157, red. J. Affelski, Poznań 2015, s. 435-556.

${ }^{4}$ M. Dąbrowska, Kafle i piece kaflowe w Polsce do końca XVIII wieku. Stan i potrzeby badawcze, Prace i Materiały Muzeum Archeologicznego i Etnograficznego w Lodzi, Seria Archeologiczna 3: 1989-1990, Łódź 1993, s. 171-178 


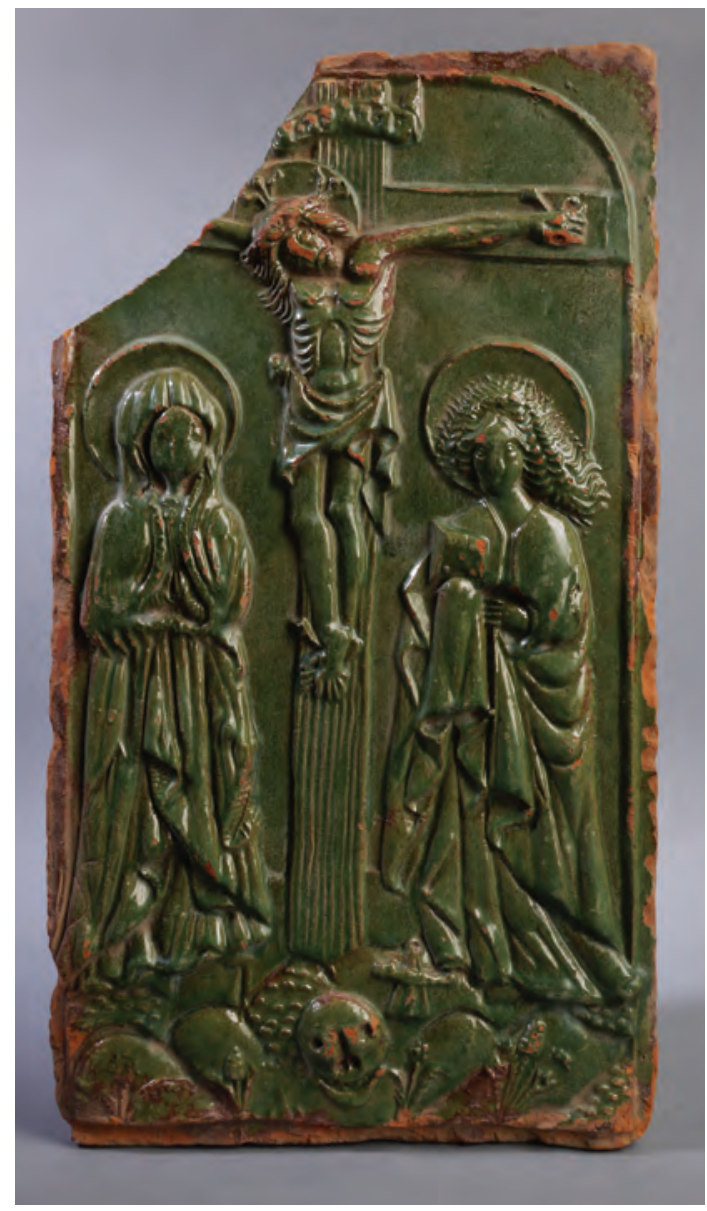

Fot. 1. Kafel z Grupą Ukrzyżowania. Fot. Kateriny Zisopulu-Bleja

ny z gliny żelazistej, a wypał przeprowadzony w atmosferze utleniającej nadał czerepowi barwę ceglastą. Komora o głębokości 9,5 cm jest w podstawie trójkątna i uformowana została z jednego prostokątnego kawałka gliny dolepionego do dłuższych boków płytki licowej (fot. 2). Otwór komory wtórnie wykrojono ostrym narzędziem już po połączeniu wszystkich składowych elementów. Typologicznie pod względem budowy nawiązuje on do grupy wyrobów określanych w literaturze przedmiotu jako: „kafle płytowe z komorą półcylindryczną"5. Jednak w przypadku omawianego egzemplarza podstawę komory stanowi trójkąt, stąd w konstrukcji przypomina on grupę wyrobów

${ }^{5}$ E. Roth Hegee, Ofenkeramik und Kachelofen. Typologie, Terminologie und Rekonstruktion im deutschsprachigen Raum ( $\mathrm{CH}, \mathrm{D}, \mathrm{A}, \mathrm{FL}$ ), Schweizer Beiträge zur Kulturgeschichte und Archäologie des Mittelalters 39, Basel 2012, s. 274. 
Fot. 2. Komora kafla z Grupą Ukrzyżowania. Poznań, ul. Za Bramką. Fot. Kateriny Zisopulu-Bleja

w typologii według M. Dąbrowskiej określonych jako: „typ II podtyp A: Komory zamknięte o podstawie trójkątnej". Datuje się je na podstawie materiałów na 1 połowę XVI wieku ${ }^{6}$. Ta odmienność konstrukcyjna wynikająca z faktu zastosowania otwartej komory jest potwierdzeniem wyjątkowości budowy kafla.

Część, która była niewidoczna po wbudowaniu kafla w bryłę pieca, opracowana została niestarannie. Na powierzchni dłuższych ścian komory niedbale wyryto ostrym narzędziem dwie linie faliste, obok nich wykonano także kilka wgłębień, w dwu przypadkach przebijając ściankę na wylot. Wewnętrzna

${ }^{6}$ M. Dąbrowska, Kafle i piece kaflowe w Polsce do końca XVIII wiek, Wrocław-WarszawaKraków-Gdańsk-Łódź 1987, s. 72; Il. 67; il. 71-75, il. 80. 
powierzchnia płytki licowej również jest nierówna i nosi ślady palców garncarza dociskających płat gliny do powierzchni matrycy. W niektórych miejscach łączenie płytki z komorą wzmocniono od wewnątrz grubymi wałkami gliny. Lico kafla nierównomiernie pokryto cynową polewą barwy zielonej, którą miejscami nałożono zbyt grubą warstwą, co spowodowało częściowe zatarcie szczegółów rysunku przedstawienia. Świadectwem niedostatecznego opanowania umiejętności warsztatowych są także braki szkliwa wyraźnie widoczne przy krawędzi płytki.

Dekoracja wykonana w technice reliefu wypukłego ukazuje scenę Ukrzyżowania przedstawioną pod schematycznie zaznaczoną arkadą (ryc. 1). Centralnym punktem kompozycji jest krzyż. Chrystus przedstawiony został z głową skłonioną w prawą stronę (fot. 3); zgodnie z ewangelicznym przekazem świadczy to o tym, że śmierć już się dokonuje: „A gdy Jezus skosztował octu, rzekł: «Wykonało się». I skłoniwszy głowę, oddał ducha” (J 19,30). Pleciona korona cierniowa podtrzymuje długie spływające na ramiona włosy. Głowę otacza nimb świętości ozdobiony dekoracją roślinną. Ciało, w którym oddano szczegóły anatomiczne rąk i torsu o wyraźnie uwydatnionych żebrach, okryte jest jedynie dekoracyjnie udrapowanym perizonium, po prawej stronie postaci zebrane w węzeł. Rozpięte na poprzecznej belce ręce i ułożone jedna na drugiej stopy przybite są do krzyża nadnaturalnej wielkości gwoździami. Nad głową Ukrzyżowanego umieszczono titulus, na powierzchni którego widać kilka schematycznych znaków naśladujących litery. W przedstawieniu krzyża zwraca uwagę różnica między pionowym słupem (truncus) z wyraźnie zaznaczoną fakturą słojów a poziomą belką o gładkiej powierzchni. Na kaflu wyobrażone są ponadto dwie osoby towarzyszące Chrystusowi: Maryja (Jego Matka) oraz Jan Ewangelista. Postać Maryi szczelnie okrywa spływająca fałdami szata, spod której widoczne są jedynie złożone do modlitwy ręce. Detale twarzy postaci zatarte są grubą warstwą polewy. Święty Jan trzyma w dłoniach widoczny atrybut, jakim jest Ewangelia, lecz poza tym ukazano go w bardziej zindywidualizowany sposób, lepiej też oddane są szczegóły jego fizjonomii. Uwagę przykuwają przede wszystkim spływające na ramiona długie, kręcone włosy. Ukazana scena rozgrywa się w skalistym krajobrazie wzgórza, którego jedyną roślinność stanowią cztery niewielkie kępki kwiatów. W dolnej części kompozycji, tuż pod krzyżem umieszczono motyw ludzkiej czaszki oraz trudny do zidentyfikowania przedmiot.

Przedstawienie Męki Pańskiej jest najczęściej ukazywanym tematem sztuki sakralnej i występuje w różnych wariantach kompozycyjnych, nawiązujących do opisu każdego z ewangelistów ${ }^{7}$. Prezentowana na kaflu scena zgodna jest z tekstem Ewangelii św. Jana: „A obok krzyża Jezusowego stały: Matka

${ }^{7}$ P. de Rynck, Jak czytać opowieści biblijne i mitologiczne w sztuce, Kraków 2009, s. 129. 
Ryc. 1. Rekonstrukcja motywu zdobniczego. Rys. Malwina Bleja

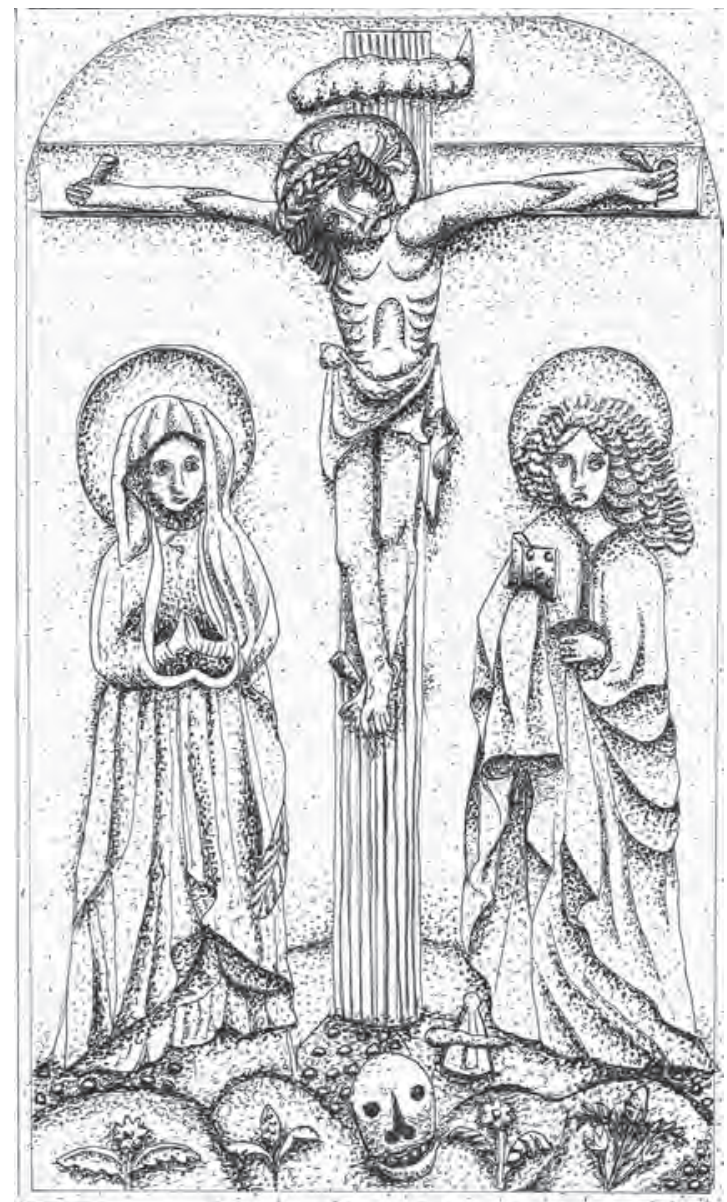

Jego i siostra Matki Jego, Maria, żona Kleofasa, i Maria Magdalena. Kiedy więc Jezus ujrzał Matkę i stojącego obok Niej ucznia, którego miłował, rzekł do Matki: «Niewiasto oto syn Twój». Następnie rzekł do ucznia: «Oto Matka twoja»" (J 19, 25-27).

Zgodnie z tradycją ikonograficzną św. Jan Ewangelista przedstawiany jest jako młodzieniec, co podkreślało, że uznawany był za najmłodszego ucznia Jezusa.

Jak już wspomniano, kafle były wytworem garncarzy, natomiast przygotowaniem matryc zajmowali się wyspecjalizowani formierze korzystający z różnych wzorów, którzy często inspirowali się grafikami znanych twórców. W przypadku omawianego kafla trudno jednoznacznie wskazać konkretny wzór graficzny, na podstawie którego wykonano jego dekorację. Można 


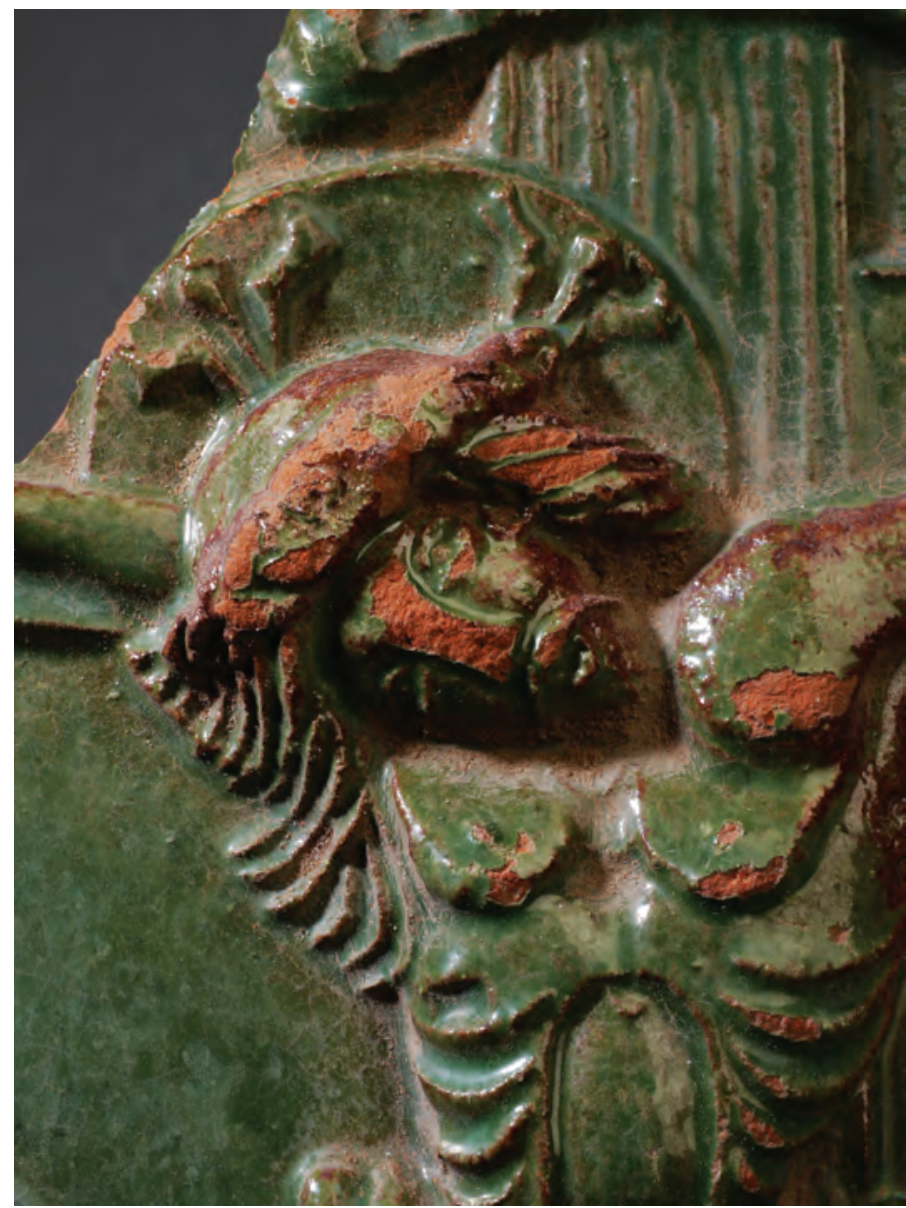

Fot. 3. Postać Chrystusa. Kafel z Grupą Ukrzyżowania. Poznań, ul. Za Bramką. Fot. Kateriny Zisopulu-Bleja

raczej przywołać grupę przedstawień podobnych pod względem kompozycyjnym i mogących stanowić inspirację dla twórcy matrycy. Wśród nich w pierwszej kolejności należy wspomnieć grafiki Mistrza E.S. (ryc. 2). Ten sam schemat przedstawieniowy Grupy Ukrzyżowania znajdujemy w pracy Martina Schongauera, który w swojej twórczości często nawiązywał do sztychów Mistrza E.S. ${ }^{8}$ Z kolei, jak wiadomo, na dziełach Schongauera wzorowali się bezpośredni i dalsi następcy ${ }^{9}$ W dekoracji kafla $\mathrm{z}$ uwagi na sposób

\footnotetext{
${ }^{8}$ W. Hütt, Niemieckie malarstwo i grafika późnego gotyku i renesansu, Warszawa 1985, s. 50.

${ }^{9}$ J. Białostocki, Sztuka XV wieku od Parlerów do Dürera, Warszawa 2010, s. 173.
} 


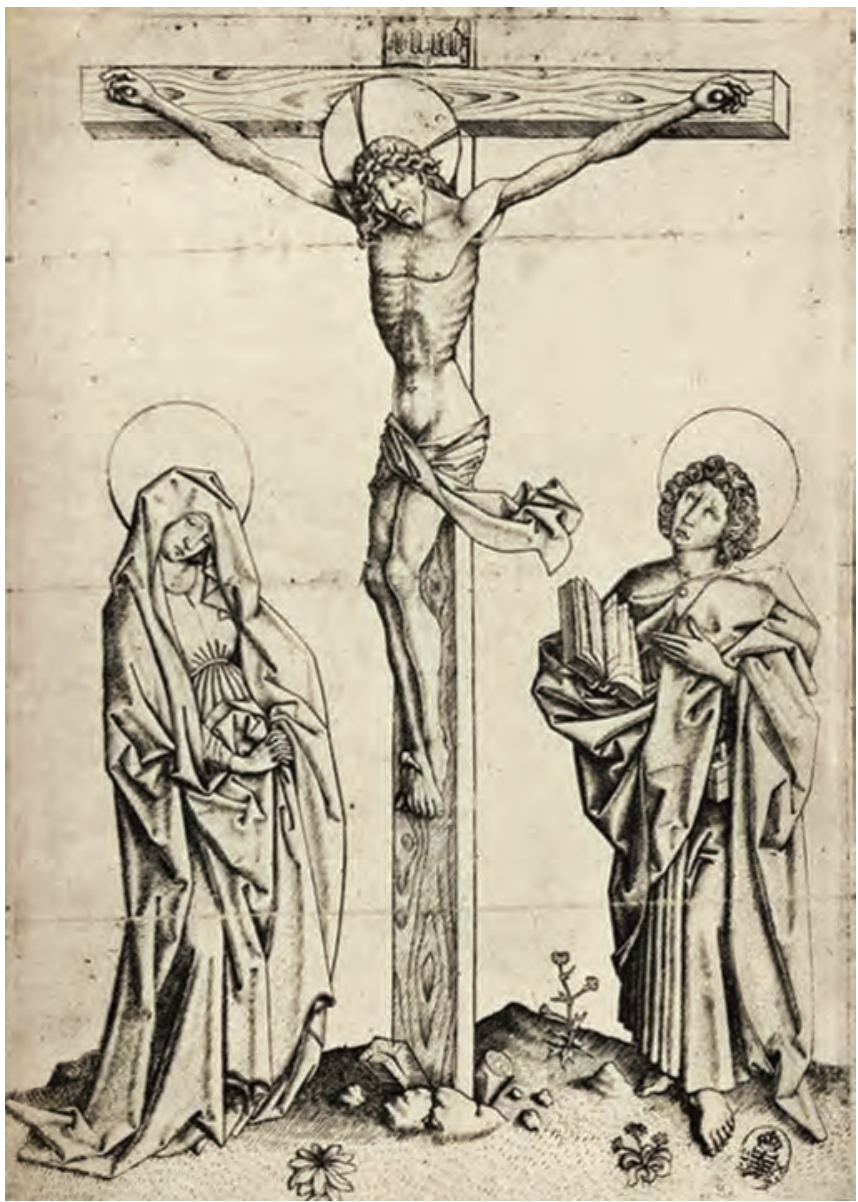

Ryc. 2. Grupa Ukrzyżowania. Mistrz E.S., ok. 1440-1467. http://www.zeno.org - Contumax GmbH \& Co. KG

oddania szczegółów postaci zauważyć można pewne podobieństwo do grafiki M. Schongauera (ryc. 3) z Grupą Ukrzyżowania (ok. 1475-1479) czy do bliźniaczo podobnego dzieła Israela van Meckenema (ok. 1490-1500). Wszyscy wymienieni twórcy pozostawali jeszcze pod silnym wpływem sztuki gotyku.

Na popularność określonych wzorów ikonograficznych miała wpływ rozwijająca się w drugiej połowie XV wieku książkowa grafika ilustracyjna oraz druki ulotne ${ }^{10}$. W wydanej nakładem Jana Hallera i Sebastiana Hybera księdze liturgicznej Missale Vratislaviense z 1505 roku, pochodzącej z pierwszej na 


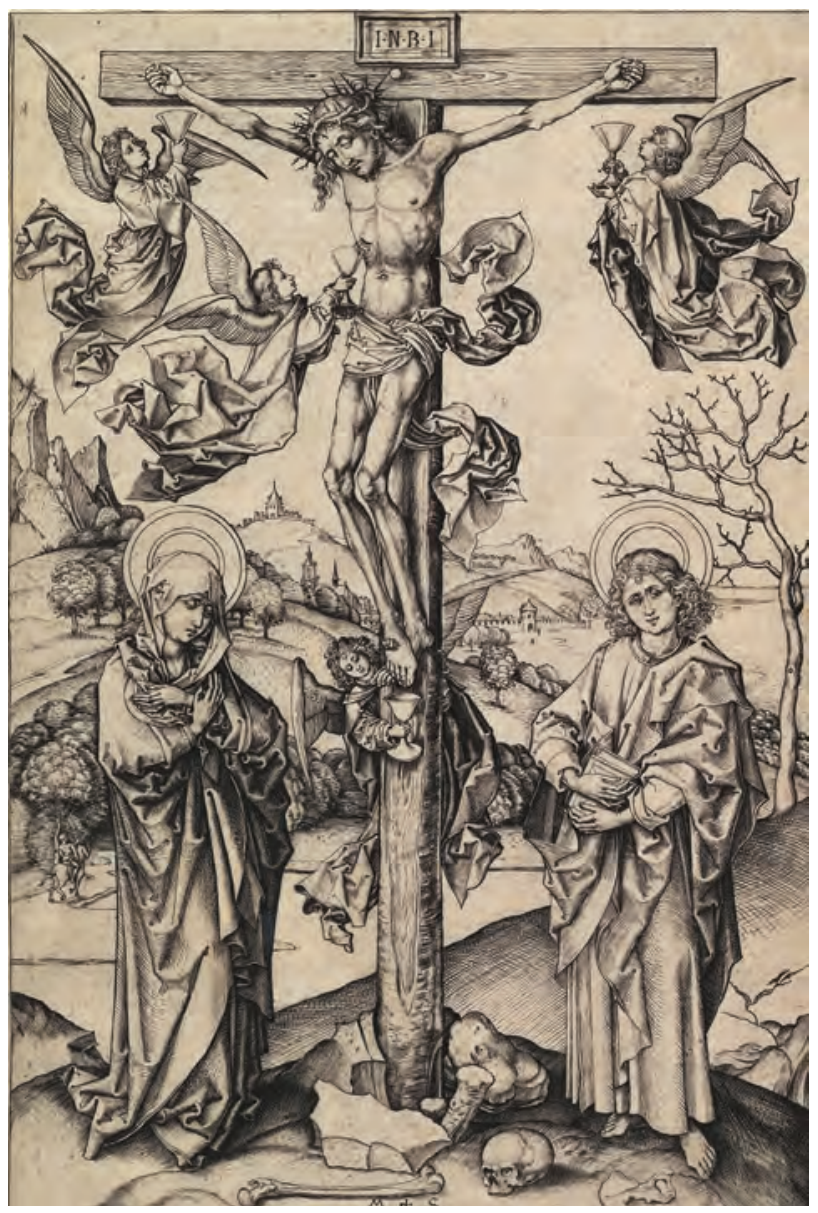

Ryc. 3. Grupa Ukrzyżowania. Martin Schongauer, ok. 1475-1479. http://www.metmuseum.org/art/collection/search/336164

terenach Polski drukarni Kaspra Hochfedera, znajduje się rycina (ryc. 4) ze sceną Ukrzyżowania podobną do znajdującej się na kaflu ${ }^{11}$. Grafika ta powstała na podstawie drzeworytu ze szkoły Wolgemuta z 1500 roku $^{12}$. Wszystko na to wskazuje, że właśnie w grafice terenu Niemiec należy upatrywać wzorów do wykonania dekoracji omawianego kafla. W dziełach religijnych tego obszaru od XV wieku do początku XVI wieku dominowały treści mistyczne

${ }^{11}$ Polonia typographica saeculi sedecimi. Zbiór podobizn zasobu drukarskiego tloczni polskich XVI stulecia, oprac. K. Piekarski, z.1, tabl. 1-28, Warszawa 1936, tabl. 15.

${ }_{12}$ M. Trojnacka, Stare druki (XVI - XVIII w.) w zbiorach Biblioteki Uniwersyteckiej KUL. Druki najstarsze, 2004, http://www.bu.kul.pl/art_10847.html [dostęp: 14.09.2017]. 


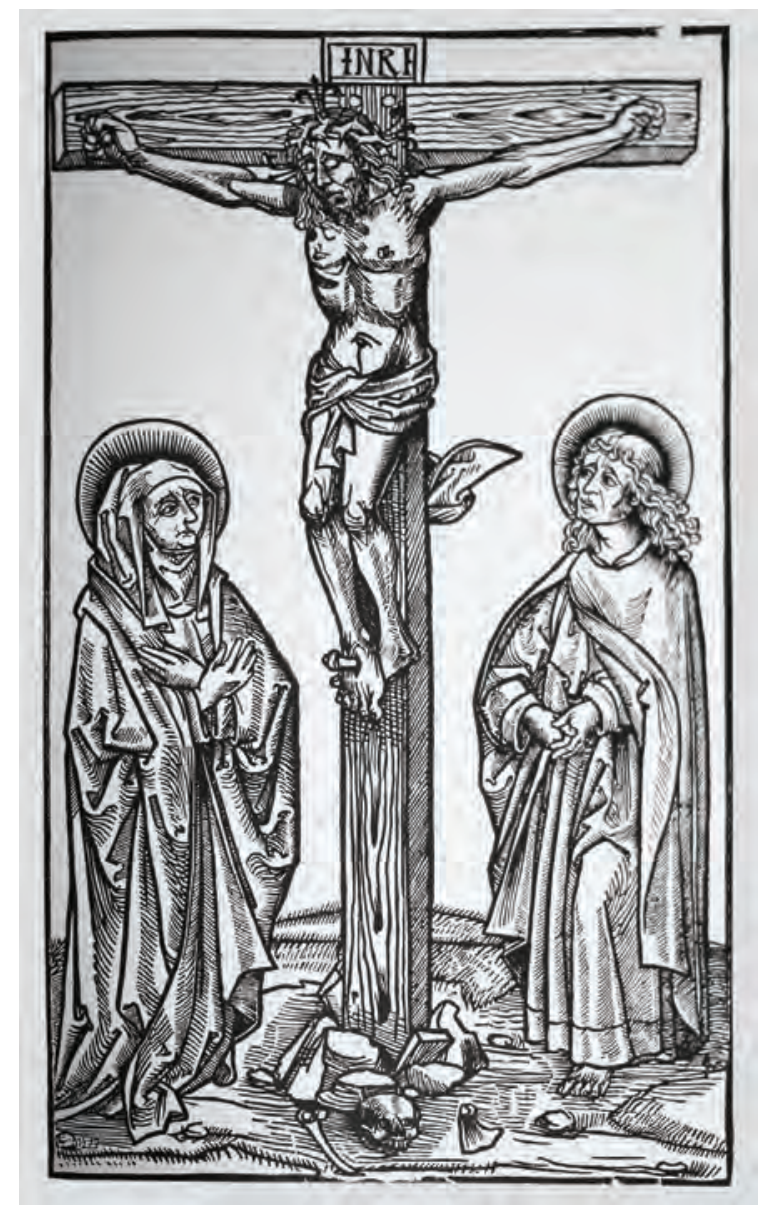

Ryc. 4. Grupa Ukrzyżowania. Missale Vratislavense: Kraków 1505. Za: Polonia typographica saeculi sedecimi. Zbiór podobizn zasobu drukarskiego tloczni polskich XVI stulecia, oprac. K. Piekarski. z. 1, tabl. 15. Warszawa 1936.

wyrażane przez sceny z życia Chrystusa, a w szczególności przez cykle pasyjne, które miały być przedmiotem kontemplacyjnych rozmyślań ${ }^{13}$. Cechą tego okresu jest realizm w ukazaniu męki i cierpienia Jezusa ${ }^{14}$, a panujące reguły określały miejsce każdego elementu w przedstawieniu. Innym charakterystycznym rysem twórczości epoki jest brak wyrażania emocji, uczucia osób ukrywano $\mathrm{w}$ znaczeniach przypisanych każdej z postaci ${ }^{15}$. Zaprezentowany

${ }^{13}$ W. Hütt, Niemieckie malarstwo, s. 79.

${ }^{14}$ B. Dąb-Kalinowska, Ziemia, piekło, raj. Jak czytać obrazy biblijne, Warszawa 1994, s. 83.

${ }^{15}$ Nowy leksykon sztuki chrześcijańskiej, tłum. O. Bobrowska-Braccini i in., red. L. Castelfranchi, M.A. Crippa Kielce 2013, s. 303. 
wcześniej szczegółowy opis dekoracji pozwala na odczytanie symbolicznych treści zawartych w przedstawieniu. Twórczość średniowiecza wykorzystywała bowiem symbol jako drogę do poznania świata pozamaterialnego ${ }^{16}$. Podbudową ideologiczną takiego postrzegania roli symbolu były teksty ojców Kościoła: Orygenesa, Pseudo-Dionizego Areopagity czy Grzegorza Wielkiego ${ }^{17}$. Celem sztuki średniowiecza, która miała charakter egzemplaryczny, wskazujący wzorce, jakimi należy kierować się w życiu, było wyrażanie poprzez symbol nieprzemijającej prawdy i piękna ${ }^{18}$.

Krzyż, jako najważniejszy symbol chrześcijański i znak zbawienia, był na przestrzeni wieków przedstawiany w różny sposób ${ }^{19}$. Wizerunek przybitego do krzyża Zbawiciela pojawia się w sztuce dopiero w VI wieku ${ }^{20}$. Sposób jego wyobrażenia również podlega ewolucji - od triumfującego nad śmiercią zwycięskiego Odkupiciela w koronie na głowie, ukazywanego z otwartymi oczami, po dominującą od XII wieku postać realistyczną - umęczonego i martwego Chrystusa. Wizerunek na kaflu odzwierciedla ten drugi sposób obrazowania, uwypuklając aspekt ludzki przejawiający się fizycznym cierpieniem Jezusa na krzyżu ${ }^{21}$. Ciało Jezusa okryte jest jedynie perizonium, co odpowiadało konwencji przedstawieniowej sztuki zachodniej. Ojcowie Kościoła przyznawali, że podobnie jak wszyscy skazańcy, Chrystus wisiał na krzyżu nagi, co było znakiem poniżenia i hańby. Według przypowieści znanych z tekstów średniowiecznych i późniejszych to Maryja miała okryć ciało Syna tkaniną zdjętą z głowy ${ }^{22}$. Korona cierniowa włożona na skronie Chrystusa jako gest szyderstwa stała się znakiem męki, bólu, cierpienia i męczeństwa (Kopliński 1990: 162), ale także królewskości Jezusa ${ }^{23}$. Według tekstów papieża Grzegorza Wielkiego każdy grzech jest cierniem, ale wskutek zrządzenia Bożego, także symbolem zbawienia ${ }^{24}$.

W rozważaniach nad Męką Chrystusa wielokrotnie przywoływany był gest skłonu głowy w prawą stronę. Orygenes widział w nim symboliczne złożenie głowy na łonie Ojca, który mógł ją orzeźwić i pokrzepić ${ }^{25}$. Prawa strona Chrystusa symbolizuje także życie wieczne (vita aeterna), lewa zaś doczesność (vita praesens), gest ten podkreśla więc zwycięstwo ducha nad zmysło-

${ }^{16}$ S. Kobielus, Dzieło sztuki dzieło wiary. Przez widzialne do niewidzialnego, Ząbki 2002, s. 214.

${ }^{17}$ S. Kobielus, Dzieło sztuki dzieło wiary, s. 210-211.

${ }^{18}$ W. Tatarkiewicz, Historia estetyki. Estetyka średniowiecza, Warszawa 1989, s. 259.

${ }^{19}$ W. Ziehr, Krzyż symbol i rzeczywistość, Warszawa-Kraków 1998, s. 52-150.

${ }^{20}$ D. Forstner, Świat symboliki chrześcijańskiej, Warszawa 1990, s. 15-16.

${ }^{21}$ S. Kobielus, Krzyż Chrystusa. Od znaku i figury do symbolu i metafory, Tyniec 2011, s. 111.

${ }^{22}$ S. Kobielus, Blask ciemności i światto niewiedzy, Ząbki 2015, s. 28-29.

${ }^{23}$ S. Kobielus, Florarium christianum. Symbolika roślin - chrześcijańska starożytność i średniowiecze, Kraków 2006, s. 163.

${ }^{24}$ M. Lurker, Stownik obrazów i symboli biblijnych, Poznań 1989, s. 38.

${ }^{25}$ S. Kobielus, Krzyż Chrystusa, s. 110. 
wością, dobra nad złem² ${ }^{26}$. Podobną wymowę ma ułożenie prawej stopy Jezusa na lewej ${ }^{27}$. W omawianej scenie ukazanej na kaflu po prawej stronie krzyża stoi Maryja, symbolizuje ona Kościół (Nowy Testament), postać Jana uosabia Synagogę (Stary Testament) ${ }^{28}$. W przekazie ewangelicznym wspominane są także gwoździe, którymi przybity był Chrystus do krzyża ${ }^{29}$. Wymienia się je wśród narzędzi Męki Pańskiej (arma Christi), w ikonografii miały one unaoczniać cierpienie i ofiarę Jezusa ${ }^{30}$. Znalazło to odzwierciedlenie w uznawaniu gwoździ z krzyża Chrystusa za ważne relikwie ${ }^{31}$.

Metaforycznego znaczenia nadano w ikonografii także widocznym na kaflu różnicom w ukazaniu ramion krzyża, co jest następstwem wielu legend opowiadających o użyciu do jego wykonania różnych gatunków drzew ${ }^{32}$. Według nich element pionowy (truncus) zrobiony został z cyprysu, który miał symbolizować życie wieczne ${ }^{33}$, a poziomy z drewna palmy oznaczającej chwałę Bożą i nieśmiertelność oraz to, co piękne, wzniosłe, doskonałe i wiekuiste ${ }^{34}$. Zgodnie z tradycją titulus sporządzony został z drewna oliwnego symbolizującego pojednanie, spokój, zgodę, miłość i oczyszczenie ${ }^{35}$. Inne źródła mówią o tym, że do wykonania tabliczki wykorzystano drewno bukszpanu z uwagi na łatwość wycinania w nim liter ${ }^{36}$. Widoczne na kaflu naśladownictwo pisma odwołuje się do umieszczania na titulusie rodzaju winy w formie skrótu INRI od łacińskiej wersji zapisu według św. Jana $(19,19)$ „Jezus Nazarejczyk, król żydowski" (Za Biblią Tysiąclecia).

Scena rozgrywa się na wzgórzu Golgoty i ikonograficznie nawiązuje do zwyczaju ukazywania krzyża w krajobrazie skalistym ${ }^{37}$. Zgodnie z przekazem ewangelistów krzyż, do którego przybito Chrystusa, umieszczono na wzgórzu zwanym Czaszka (Mt 27,33; Mk 15,22; Łk 23,33; J 19,17), stąd jej wyobrażenie w dole sceny. Teksty ojców Kościoła widziały w miejscu stracenia Chrystusa pępek świata, a także miejsce pochówku Adama - pierwszego człowieka. Łączono więc z nim motyw czaszki pod krzyżem, która odtąd miała

${ }^{26}$ T. Dobrzeniecki, U źrodeł przedstawień „,Tronu Laski” i „,Pietas Domini”, „Rocznik Muzeum Narodowego w Warszawie" 15/1(1971), s. 221-312. M. Lurker, Słownik obrazów i symboli biblijnych, s. $186-187$.

${ }^{27}$ S. Kobielus, Krzyż Chrystusa, s. 99.

${ }^{28}$ M. Lurker, Stownik obrazów i symboli biblijnych, s. 187.

${ }^{29}$ S. Kobielus, Krzyż Chrystusa, s. 94.

${ }^{30}$ Encyklopedia katolicka, t. 13, Lublin 2009, kol. 769.

${ }^{31}$ S. Kobielus, Krzyż Chrystusa, s. 99.

32 Tamże, s. 62-65.

${ }^{33}$ S. Kobielus, Florarium christianum, s. 50.

${ }^{34}$ D. Forstner, Świat symboliki, s. 175; S. Kobielus, Krzyż Chrystusa, s. 62-63; J. Sprutta, Krzyż mistyczny jako Drzewo Życia w sztuce średniowiecznej, „Studia Gnesnensia” 29(2015), s. 332.

${ }^{35}$ S. Kobielus, Krzyż Chrystusa, s. 64.

${ }^{36}$ S. Kobielus, Florarium christianum, s. 38.

${ }^{37}$ S. Kobielus, Blask ciemności i światto niewiedzy, s. 122. 
symbolizować zwycięstwo Chrystusa nad śmiercią ${ }^{38}$ i podkreślić Jego ofiarę w odkupieniu ludzkich grzechów ${ }^{39}$. Nazwa Wzgórze lub Miejsce Czaszki ma też kilka odniesień tak do samego kształtu wzniesienia przypominającego ludzką głowę, jak i do funkcji miejsca, w którym odbywały się publiczne egzekucje, stąd można tam było spotkać rozrzucone kości ofiar porzuconych ptakom na pożarcie ${ }^{40}$. Wszystko to znalazło odzwierciedlenie w dekoracji kafla. W jej analizie wspomnieć też trzeba o niezidentyfikowanym przedmiocie leżącym na ziemi tuż pod krzyżem (fot. 4). Być może są to kości ludzkie lub narzędzia męki Pańskiej, oba elementy były często wykorzystywane w przedstawieniach pasyjnych Golgoty.

Nie bez znaczenia jest także roślinność widoczna w dole kafla, ona także ma symboliczną konotację i łączy się z ideą, w myśl której Ukrzyżowanie dokonało się na górze rajskiej ${ }^{41}$. Technika, w jakiej wykonany jest kafel, oraz jednobarwność dekoracji utrudnia jednoznaczne rozpoznanie roślin widocznych w przedstawieniu. Same kwiaty nawiązują do kwietnej łąki charakterystycznej dla wiosny lub wczesnego lata ${ }^{42}$. Roślinność, którą można rozpoznać przede wszystkim na podstawie malarskich dzieł o tematyce pasyjnej, była ściśle określona. Wśród nich wymienia się mniszka pospolitego, który oznacza początek męki Pańskiej z powodu tego, że miał być spożywany podczas ostatniej wieczerzy ${ }^{43}$. Inną rośliną wykorzystywaną w ikonografii pasyjnej była babka. Niewykluczone, że to ją przedstawiono na kaflu (fot. 4), babka w okresie kwitnienia wytwarza charakterystyczny walcowaty lub kulisty kłos. Jej zdolność szybkiego rozprzestrzeniania się łączono z rozszerzaniem się chrześcijaństwa. Babka uważana jest także za symbol pokory Matki Bożej ${ }^{44}$. Wśród szaty roślinnej scen pasyjnych można rozpoznać: konwalię oznaczającą łzy Matki Bożej, oset symbolizujący grzech, śmierć, smutek i mękę Chrystusa, a także dziewannę i dziurawiec ${ }^{45}$ oraz mak, którego barwa przywołuje męczeńską śmierć na krzyżu ${ }^{46}$. Przedstawione symboliczne odniesienia wskazują, że dekoracja kafla oddaje sposoby obrazowania Ukrzyżowania charakterystyczne dla okresu późnego średniowiecza.

${ }^{38}$ S. Kobielus, Krzyż Chrystusa, s. 80.

${ }^{39}$ S. Zuffi, Nowy Testament. Postacie i epizody, Warszawa 2007, s. 291.

${ }^{40}$ S. Kobielus, Blask ciemności i światlo niewiedzy, s. 122; S. Carr-Gromm, Stownik symboli w sztuce. Motywy, mity, legendy w malarstwie i rzeźbie, Warszawa 2005, s. 53.

${ }^{41}$ S. Kobielus, Blask ciemności i światło niewiedzy, s. 121.

42 Tamże, s. 123.

${ }^{43}$ S. Kobielus, Blask ciemności i światto niewiedzy, s. 124.

${ }^{44}$ S. Kobielus, Blask ciemności i światto niewiedzy, s. 124.

${ }^{45}$ S. Kobielus, Florarium christianum, s. 64-65, 110; S. Kobielus, Blask ciemności i światto niewiedzy, s. 125.

${ }^{46}$ L. Impelluso, Natura i jej symbole. Rośliny i zwierzęta, Warszawa 2006, s. 111. 


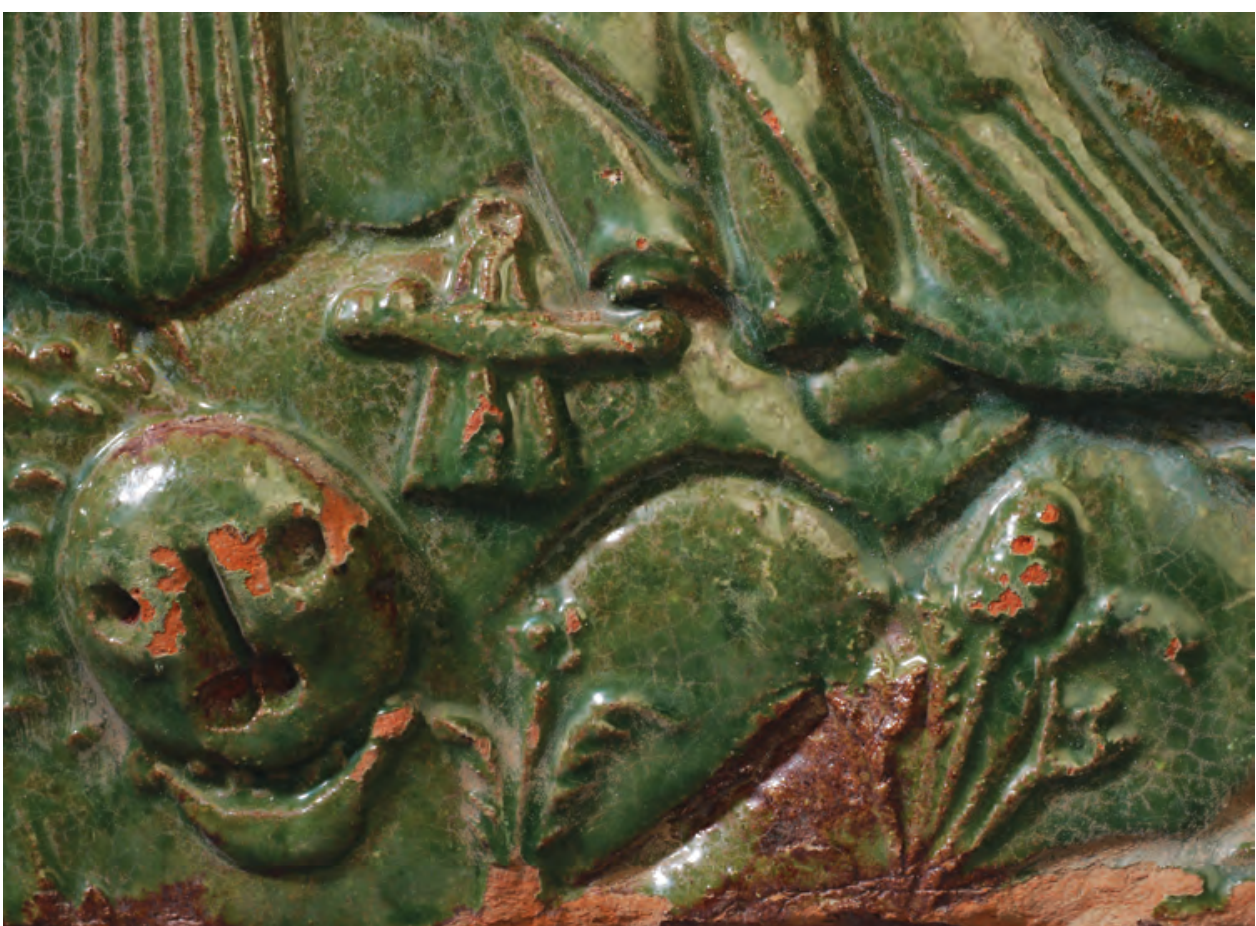

Fot. 4. Szczegóły dekoracji. Kafel z Grupą Ukrzyżowania. Poznań, ul. Za Bramką. Fot. Kateriny Zisopulu-Bleja

W ustaleniach chronologicznych dotyczących zabytku pomocna może być także analiza cech technologicznych. Istotne znaczenie ma w tym przypadku użycie kryjącej polewy ołowiowo-cynowej znanej w kaflarstwie polskim dopiero od XVI wieku ${ }^{47}$. Wcześniej, bo w końcu XV wieku, umiejętność tę posiedli garncarze $\mathrm{z}$ terenu Niemiec ${ }^{48}$. Wobec powyższego, pomimo licznych cech omawianego kafla charakterystycznych dla stylistyki gotyckiej, należy go datować na pierwszą ćwierć XVI wieku. Interesująca jest próba porównania dekoracji omawianego egzemplarza do znanych przykładów kafli pochodzących z tego samego okresu. Początek XVI wieku to czas przeżywania się elementów gotyckich i pojawienia się nowych renesansowych trendów ${ }^{49}$. W samym Poznaniu z tego czasu znane są przede wszystkim kafle niszowe,

${ }^{47}$ M. Dąbrowska, Kafle i piece kaflowe, s. 204.

${ }^{48}$ R. Franz, Der Kachelofen. Entstehung und kunstgeschichtliche Entwicklung vom Mittelalter bis zum Ausgang des Klassizmus, Graz 1969, s. 15-37, 39-69.

${ }^{49}$ M. Piątkiewicz-Dereniowa, Kafle wawelskie okresu wczesnego renesansu, „Studia z Dziejów Wawelu" 2 (1960), s. 303-372; M. Dąbrowska, Kafle i piece kaflowe w Polsce do końca XVIII wiek, Wrocław-Warszawa-Kraków-Gdańsk-Łódź 1987, s. 126-127; E. Kilarska, M. Kilarski, Kafle z terenu 
figuralne, zdominowane wyobrażeniami świętych umieszczanych na wklęsłej powierzchni kafla. Właściwie prawie wszystkie dotychczas znane przykłady z Poznania reprezentują ten sam typ reliefowego wizerunku świętego przedstawianego na plastycznym postumencie $\mathrm{z}$ wicią roślinną $\mathrm{z}$ boku postaci. Pierwszy opublikowany kafel niszowy znaleziony został w 1910 roku przy budowie domu przy ul. Za Bramką. Przedstawienie, jak sądzono, św. Gertru$d y^{50}$ - w rzeczywistości ukazywało postać św. Doroty, na co wskazują atrybuty: koszyk i róże. Niestety, ten pokryty wielobarwnymi polewami kafel znany jest jedynie ze zdjęcia, pochodził bowiem z prywatnej kolekcji poznańskiego przedsiębiorcy budowlanego Ludwika Frankiewicza bądź jego syna Mariana. Drugi typ kafla niszowego odkryto podczas badań na ul. Żydowskiej 11. Postać znajdująca się na nim zinterpretowana jest jako zakonnik w stroju kamedulskim ${ }^{51}$. Na podstawie trzech węzłów widocznych na sznurze, którym przepasana jest postać, można jednak sądzić, że jest to jeden z grona świętych franciszkańskich. Zgodnie z regułą franciszkanie składają śluby ubóstwa, posłuszeństwa i czystości, które symbolizują trzy węzły.

Mały fragment kafla niszowego znaleziono na ul. Masztalarskiej ${ }^{52}$, a inne niewielkie ułamki odkryto podczas badań na tym samym stanowisku na ul. Za Bramką, z których pochodzi egzemplarz z Grupą Ukrzyżowania ${ }^{53}$. Z kolei z poznańskiego Ostrowa Tumskiego znany jest zachowany prawie w całości jednobarwny kafel niszowy z wyobrażeniem Madonny z Dzieciątkiem, odkryty podczas badań wnętrza kanonii $\mathrm{nr} 6^{54}$. Natomiast inny, wielobarwny z wizerunkiem św. Jerzego pochodzi z badań archeologicznych prowadzonych na ul. Posadzego ${ }^{55}$. Odmienny pod względem budowy od wcześniej wymienionych jest kafel płytowy z początku XVI wieku, znaleziony podczas badań klasztoru podominikańskiego ${ }^{56}$; na płytce licowej wyobrażono postać

Prus Królewskich, Malbork 2009, s. 22-34; M. Majewski, Renesansowe kafle zachodniopomorskie. Studium z historii ogrzewania wnętrz mieszkalnych, Stargard-Szczecin 2015, s. 123-125.

${ }^{50}$ M. Gumowski, Kafle średniowieczne w Muzeum Wielkopolskim, „Rocznik Muzeum Wielkopolskiego w Poznaniu", t. III, 1928, s. 141-142, tabl. IX-24.

${ }^{51}$ P. Wawrzyniak, Kafle piecowe w zbiorach byłej Pracowni Naukowo-Badawczej PKZ Sp. z o.o. w Poznaniu, „Wielkopolskie Sprawozdania Archeologiczne” t. 6 (2003), s. 190; 194: ryc. 4:1-2.

${ }^{52}$ K. Zisopulu-Bleja Kafle piecowe, fot. D1-12.

${ }^{53} \mathrm{~K}$. Zisopulu-Bleja, Kafle piecowe (XV-XVIII w.), ryc. 29-f; 30-e; 33c; 43-h.

${ }^{54}$ N. Gryzińska-Sawicka, M. Poklewska-Koziełl, Kafel z wyobrażeniem Madonny z Dzieciątkiem. Z badań archeologicznych na poznańskim Ostrowie Tumskim, „Ecclesia. Studia z Dziejów Wielkopolski” 9 (2014), s. 91-108.

55 P. Wawrzyniak, Kafle piecowe z ul. Posadzego na Ostrowie Tumskim w Poznaniu, [w:] Civitas Posnaniensis. Studia z dziejów średniowiecznego Poznania, red. Z. Kurnatowska, T. Jurek, Poznań 2005, s. 408; 412, ryc. 3.

${ }^{56}$ M. Piątkiewicz-Dereń, Materiat kaflowy, [w:] Początki i rozwój Starego Miasta w Poznaniu $w$ świetle badań archeologicznych i urbanistyczno-architektonicznych, red. W. Błaszczyk, Warszawa 1977, s. 194, ryc. 2-b. 


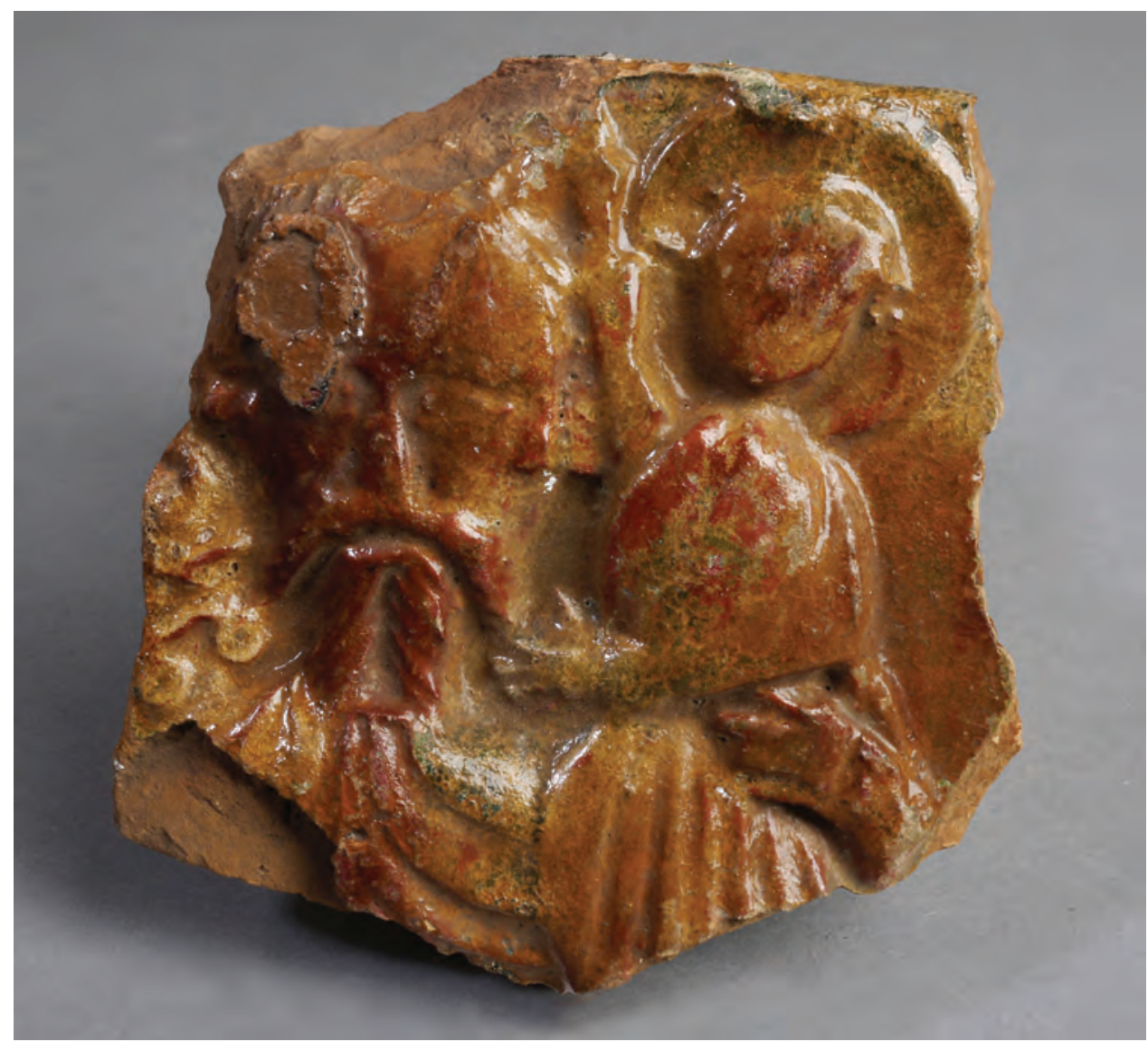

Fot. 5. Kafel z przedstawieniem św. Krzysztofa z Dzieciątkiem Jezus. Klasztor dominikański. Poznań, ul. Grabary 75/77. Zbiory Muzeum Archeologicznego w Poznaniu. Fot. Kateriny Zisopulu-Bleja

św. Krzysztofa z Dzieciątkiem Jezus na barku (fot. 5). Wobec tak szczupłych danych źródłowych trudno dokonywać jakichkolwiek uogólnień. Należy jednak podkreślić, że wszystkie wymienione przykłady to kafle o tematyce religijnej. Motyw Ukrzyżowania znany jest $\mathrm{z}$ gotyckich kafli z Gniezna ${ }^{57}$. Na jednym z nich, pochodzącym z badań Jeziora Świętego, gdzie znaleziono liczne destrukty pieców, widoczna jest górna część krzyża i fragment głowy Chrystusa. Wydaje się, że detale są identyczne jak na analizowanym kaflu poznańskim, stąd do produkcji obu mogła być wykorzystana ta sama matryca. W świetle dotychczasowych ustaleń trudno się jednak zgodzić z przyjętym

${ }^{57}$ T. Janiak, Kafle gotyckie w zbiorach Muzeum Początków Państwa Polskiego w Gnieźnie, Gniezno 2003, s. 86, il. 148-149. 
datowaniem kafla gnieźnieńskiego na połowę XV wieku ${ }^{58}$. Szukając analogii, nie można pominąć kafla niszowego wbudowanego w ścianę kamienicy mieszczańskiej w Stargardzie, datowanego na początek XVI wieku, który jakkolwiek odmienny pod względem budowy, wykazuje w dekoracji wiele cech zbieżnych z poznańskim egzemplarzem ${ }^{59}$. Jak można zauważyć, materiał porównawczy ogranicza się do pojedynczych kafli, brakuje natomiast, nie tylko na gruncie poznańskim, dobrze datowanych zespołów z pieców pochodzących z konkretnych budynków. Lukę tę po części wypełnia zespół kafli znaleziony na wrocławskim Ostrowie Tumskim datowany na 2 połowę XV i 1 ćwierć XVI wieku, związany z jednym z dworów kanoniczych, w cechach budowy przypominający analizowany kafel z Poznania ${ }^{60}$. Jest on interesujący także $\mathrm{z}$ uwagi na treść programu ikonograficznego, gdzie w jednym piecu łączono dominujące pod względem liczebności kafle o tematyce religijnej (postaci świętych), heraldycznej, roślinnej i wykorzystującej motywy architektoniczne. Jak wyglądał zestaw tematyczny dekoracji pieca, w który wbudowano kafel ze sceną Ukrzyżowania, trudno orzec. Warto w tym miejscu przywołać repertuar przedstawieniowy późnogotyckich kafli z Saksonii, określanych jako grupa Halberstadt, datowanych na koniec XV wieku i 1 połowę XVI wieku' ${ }^{61}$, w dekoracji których dominują przedstawienia świętych z ich atrybutami, sceny maryjne, heraldyczne, pasyjne, w tym także odnotowano przedstawienie Chrystusa na Krzyżu w towarzystwie Marii i Jana Ewangelisty czy wizerunki elektorów saskich ${ }^{62}$. Interesujący w aspekcie analizy programów ikonograficznych jest piec z 1501 roku stojący po dziś dzień w Złotej Komnacie na zamku w Hohensalzburgu ${ }^{63}$. W jego bogatej dekoracji wykorzystano motywy maryjne, liczne postaci świętych; co istotne, na jednym z kafli prezentowane są także treści pasyjne, całość uzupełniają egzemplarze z ornamentem roślinnym ${ }^{64}$.

Wielkość i forma analizowanego tutaj kafla oraz nachylenie ścianek komory wskazują, że mógł on być wbudowany w skrzynię pieca w kształcie graniastosłupa o podstawie wielokątnej. Na terenie Polski brak zachowanych oryginalnych urządzeń grzewczych z początków XVI wieku. Wśród znanych pieców zachowanych w Europie Zachodniej można wymienić oryginalne piece z Meranu z końca XV wielu i wspomniany wcześniej z zamku w Hohen-

${ }^{58}$ T. Janiak, Kafle gotyckie w zbiorach Muzeum Początków Państwa Polskiego w Gnieźnie, s. 86.

${ }^{59}$ M. Majewski, Renesansowe kafle zachodniopomorskie, s. 27; 123-125.

${ }^{60}$ E. Lisowa, C. Lasota, Późnogotyckie kafle z Ostrowa Tumskiego, „Silesia Antiqua” 31(1989), s. $83-102$.

${ }^{61} \mathrm{~K}$. Strauss, Die Kachelkunst des 15. und 16. Jahrhunderts in Deutschland, Österreich und der Schweiz, Straßburg 1966, s. 20-37.

${ }^{62}$ Tamże, s. 21-25.

${ }^{63}$ R. Franz, Der Kachelofen, s. 58-61.

${ }^{64}$ Tamże, s. 59; Abb. 129. 
salzburgu z początku XVI wieku ${ }^{65}$. Ponadto odwołać się można do licznych rekonstrukcji kaflowych urządzeń grzewczych z tego okresu ${ }^{66}$. Przytoczone przykłady wskazują na budowę pieców opartych na konstrukcji składającej się $\mathrm{z}$ dolnej prostopadłościennej skrzyni i nadstawy w formie walca. Ciekawym przykładem rekonstrukcji był piec z Leibnizhaus w Hannowerze (zniszczony podczas wojny), zbudowany z kafli pochodzących z Goslaru, reprezentujących grupę Halberstadt, w którym nadstawa ze względu na duże rozmiary kafli była w podstawie wielokątnej ${ }^{67}$. Podobne przypuszczenia co do kształtu urządzeń grzewczych z terenu Polski datowanych na początek XVI wieku formułują także polscy badacze ${ }^{68}$.

Dotychczas nie odkryto w Poznaniu warsztatów garncarskich produkujących kafle gotyckie i wczesnorenesansowe. Koncentrujące się na Świętym Wojciechu garncarnie według dotychczas pozyskanych źródeł archeologicznych wytwarzały kafle od około połowy XVI wieku do początku XVII wie$\mathrm{ku}^{69}$. Wobec powyższego trudno ocenić, czy omawiany kafel jest wyrobem miejscowym, czy może sprowadzonym z innego ośrodka. Trzeba jednak podkreślić, że pod względem wielkości i budowy odbiega on od wszystkich do tej pory znanych $\mathrm{z}$ terenu miasta.

Znalezienie kafla w fosie miejskiej ze względów oczywistych nie pozwala na wskazanie budynku, w jakim stał piec, którego był częścią. W najbliższym sąsiedztwie badanego stanowiska znajdowała się kolegiata pw. św. Marii Magdaleny. W otoczeniu głównej świątyni lokacyjnego Poznania, zwłaszcza po zaprzestaniu w tym miejscu pochówków i założeniu w 1418 roku nowego cmentarza na Piaskach, notuje się od lat 60 . XV wieku intensywną zabudowę terenu ${ }^{70}$. Obszar ten zamieszkiwali przede wszystkim księża altarzyści związani z kościołem kolegiackim ${ }^{71}$. Ponadto wschodnią część starego cmentarza zajmowało probostwo farne, a sześć wykuszy murów miejskich zaadoptowanych na mieszkania również z czasem przechodziło na własność fundacji altaryjnych $^{72}$. Wspomnieć też trzeba o istnieniu w bezpośredniej bliskości innych

${ }^{65}$ E. Roth Hegee, Ofenkeramik und Kachelofen, 27, Abb. 110; 136, Abb. 230

${ }^{66}$ R. Franz, Der Kachelofen, s. 44-69.

${ }^{67}$ K. Strauss, Die Kachelkunst des 15. und 16. Jahrhunderts in Deutschland, Tafel 6.

68 M. Piątkiewicz-Dereniowa, Kafle wawelskie okresu wczesnego renesansu, s. 356-361; M. Dąbrowska, Kafle i piece kaflowe, s. 161.

${ }^{69}$ T. Łaszkiewicz, Renesansowa garncarnia (kaflarnia) na Wzgórzu Św. Wojciecha w Poznaniu, [w:] Kafle gotyckie i renesansowe na ziemiach polskich (katalog wystawy), Gniezno 1993, s. 44-45; P. Wawrzyniak, Kafle piecowe w zbiorach bylej Pracowni Naukowo-Badawczej, s. 194-196; J. Kaczmarek, Z. Karolczak, K. Zisopulu-Bleja, Archeologia o przeszłości międzyrzecza Warty, Rudnika i Wierzbaka, „Kronika Miasta Poznania” 4 (2012), s. 19-26.

${ }^{70}$ J. Wiesiołowski, Socjotopografia późnośredniowiecznego Poznania, Poznań 1997, s. 159.

${ }^{71}$ Z. Kurzawa, A. Kusztelski, Antiquum coemetrium. Plac Kolegiacki, jego ksztaltowanie, funkcje i zmiany zabudowy, „Kronika Miasta Poznania” 3(2003), s. 221.

${ }^{72}$ J. Wiesiołowski, Socjotopografia późnośredniowiecznego Poznania, s. 156. 
ważnych obiektów, jak kościół i szpital św. Gertrudy (od 1456 r.), a w sąsiedztwie Ciemnej Bramki - szkoły miejskiej związanej z kolegiatą ${ }^{73}$. Wszystko to potwierdza, że wskazany rejon miasta był zamieszkiwany głównie przez duchowieństwo i w tym środowisku można upatrywać domniemanego fundatora pieca, z którego pochodził omawiany kafel. Krąg odbiorców kaflowych urządzeń grzewczych był ograniczony, co ważne, w okresie upowszechniania się pieców w Wielkopolsce notuje się szczególnie dużo odkryć związanych właśnie z obiektami kościelnymi ${ }^{74}$.

Bogato dekorowany piec uznać można za swoiste medium odzwierciedlające istotne treści ideowe okresu, w jakim powstawal ${ }^{75}$. Omawiany kafel w warstwie tematycznej wpisuje się w ważny rys polskiej kultury religijnej okresu późnego średniowiecza, w którym dominują wątki pasyjne realizowane w sztuce, piśmiennictwie, liturgii i myśli teologicznej ${ }^{76}$. Były one kontynuowane także w wieku XVI ${ }^{77}$.

\author{
„WE GREET YOU, THE CROSS OF GOD ALMIGHTY” \\ A TILE FROM ARCHAEOLOGICAL RESEARCH \\ AT ZA BRAMKĄ STREET IN POZNAN
}

\title{
Summary
}

The subject of the article is a tile with the representation of the Crucifixion Group discovered during archaeological research in the municipal moat at Za Bramką Street in Poznan. Tiles were a product of pottery craft, while their ornamentation was subject to the variability associated with the current prevailing trends and decorative styles. This monument is dated to the beginning of the sixteenth century, its decoration was made based on Gothic graphic patterns and symbolism characteristic of the passion art of this period. The place where the tile was found may indicate the founder of the stove derived from the circle of clerics who lived in the immediate vicinity of the collegiate church of St. Mary Magdalene.

${ }^{73}$ J. Łukaszewicz, Obraz historyczno-statystyczny miasta Poznania $w$ dawniejszych czasach, t. II, Poznań 1998, s. 8, 107.

${ }^{74}$ T. Janiak, Kafle gotyckie z Wielkopolski, [w:] Średniowieczne i nowożytne kafle. Regionalizmy-Podobieństwa-Różnice, red. M. Dąbrowska, H. Karwowska, Białystok 2007, s. 34.

${ }^{75}$ M. Dąbrowska, Piec jako nośnik idei?, „Archaeologia Historica Polona” 21 (2013), s. 210-235 .

${ }^{76}$ J. Kopeć, Nurt pasyjny w średniowiecznej religijności polskiej, [w:] Męka Chrystusa wczoraj i dziś, red. H. Wojtasik, Lublin 1981, s. 53-60.

${ }^{77}$ H. Wojtasik, Męka Chrystusa w religijności polskiej XVI-XVIII w., [w:] Męka Chrystusa wczoraj i dziś, red. H. Wojtasik, Lublin 1981, s. 61-62; 79. 
Słowa kluczowe: archeologia, kafle, Grupa Ukrzyżowania, wzory graficzne, symbolika

Keywords: archaeology, tiles, Crucifixion Group, graphic patterns, symbols

\section{Bibliografia}

Białostocki J., Sztuka XV wieku od Parlerów do Dürera, Warszawa 2010.

Carr-Gromm S., Stownik symboli w sztuce. Motywy, mity, legendy w malarstwie i rzeźbie, Warszawa 2005.

Dąb-Kalinowska B., Ziemia, piekło, raj. Jak czytać obrazy biblijne, Warszawa 1994.

Dąbrowska M., Kafle i piece kaflowe w Polsce do końca XVIII wiek, Wrocław-Warszawa-Kraków-Gdańsk-Łódź 1987.

Dąbrowska M., Kafle i piece kaflowe w Polsce do końca XVIII wieku. Stan i potrzeby badawcze, Prace i Materiały Muzeum Archeologicznego i Etnograficznego w Łodzi, Seria Archeologiczna 3: 1989-1990: 1993, s. 171-177.

Dąbrowska M., Piec jako nośnik idei?, „Archaeologia Historica Polona” 21 (2013), s. 209-237.

Dobrzeniecki T., U źródet przedstawień ,, Tronu Laski” i „Pietas Domini”, „Rocznik Muzeum Narodowego w Warszawie" 15/1(1971), s. 221-312.

De Rynck P., Jak czytać opowieści biblijne i mitologiczne w sztuce, Kraków 2009.

Encyklopedia katolicka, t. 13, Lublin 2009.

Forstner D., Świat symboliki chrześcijańskiej, Warszawa 1990.

Franz R., Der Kachelofen. Entstehung und kunstgeschichtliche Entwicklung vom Mittelalter bis zum Ausgang des Klassizmus, Graz 1969.

Gumowski M., Kafle średniowieczne w Muzeum Wielkopolskim, „Rocznik Muzeum Wielkopolskiego w Poznaniu”, t. III, 1928, s. 123-167.

Gryzińska-Sawicka N., Poklewska-Koziełł M., Kafel z wyobrażeniem Madonny z Dzieciatkiem. Z badań archeologicznych na poznańskim Ostrowie Tumskim, „Ecclesia. Studia z Dziejów Wielkopolski" 9 (2014), s. 91-108.

Hütt W., Niemieckie malarstwo i grafika późnego gotyku i renesansu, Warszawa 1985.

Impelluso L., Natura i jej symbole. Rośliny i zwierzęta, Warszawa 2006.

Janiak T., Kafle gotyckie w zbiorach Muzeum Poczatków Państwa Polskiego w Gnieźnie, Gniezno 2003.

Janiak T., Kafle gotyckie z Wielkopolski, [w:] Średniowieczne i nowożytne kafle. Regionalizmy-Podobieństwa-Różnice, red. M. Dąbrowska, H. Karwowska, Białystok 2007, s. 17-35.

Kaczmarek J., Karolczak Z., Zisopulu-Bleja K., Archeologia o przeszłości międzyrzecza Warty, Rudnika i Wierzbaka, „Kronika Miasta Poznania” 4 (2012), s. 7-28.

Kilarska E., Kilarski M., Kafle z terenu Prus Królewskich, Malbork 2009.

Kobielus S., Dzieło sztuki dzieło wiary. Przez widzialne do niewidzialnego, Ząbki 2002.

Kobielus S., Florarium christianum. Symbolika roślin - chrześcijańska starożytność i średniowiecze, Kraków 2006.

Kobielus S., Krzyż Chrystusa. Od znaku i figury do symbolu i metafory, Tyniec 2011.

Kobielus S., Blask ciemności i światto niewiedzy, Ząbki 2015.

Kopaliński W., Stownik symboli, Warszawa 1990.

Kopeć J., Nurt pasyjny w średniowiecznej religijności polskiej, [w:] Męka Chrystusa wczoraj i dziś, red. H. Wojtasik, Lublin 1981, s. 31-60.

Kurzawa Z., Kusztelski A., Antiquum coemetrium. Plac Kolegiacki, jego kształtowanie, funkcje i zmiany zabudowy, „Kronika Miasta Poznania” 3(2003), s. 217-240. 
Lisowa E., Lasota C., Późnogotyckie kafle z Ostrowa Tumskiego, „Silesia Antiqua” 31(1989), s. 83-104. Lurker M., Stownik obrazów i symboli biblijnych, Poznań 1989.

Łaszkiewicz T., Renesansowa garncarnia (kaflarnia) na Wzgórzu Św. Wojciecha w Poznaniu, [w:] Kafle gotyckie i renesansowe na ziemiach polskich (katalog wystawy), Gniezno 1993, s. 44-45.

Łukaszewicz J., Obraz historyczno-statystyczny miasta Poznania w dawniejszych czasach, t. II, Poznań 1998.

Majewski M., Renesansowe kafle zachodniopomorskie. Studium z historii ogrzewania wnętrz mieszkalnych, Stargard-Szczecin 2015.

Nowy leksykon sztuki chrześcijańskiej, tłum. O. Bobrowska-Braccini i in., red. L. Castelfranchi, M.A. Crippa Kielce 2013.

Piątkiewicz-Dereniowa M., Materiat kaflowy, [w:] Początki i rozwój Starego Miasta w Poznaniu $w$ świetle badań archeologicznych i urbanistyczno-architektonicznych, red. W. Błaszczyk, Warszawa 1977, s. 193-205.

Piątkiewicz-Dereniowa M., Kafle wawelskie okresu wczesnego renesansu, „Studia z Dziejów Wawelu" 2 (1960), s. 303-374.

Polonia typographica saeculi sedecimi. Zbiór podobizn zasobu drukarskiego tłoczni polskich XVI stulecia, oprac. K. Piekarski, z.1, tabl. 1-28, Warszawa 1936.

Pospieszna B., Późnośredniowieczne kafle z kościoła pod wezwaniem św. Walentego w Matarni pod Gdańskiem, [w:] Materiały Sesji Oddziału Warszawskiego Stowarzyszenia Historyków Sztuki, t. II, red. R. Bobrow, Warszawa 2001, s. 79-93.

Roth Hegee E., Ofenkeramik und Kachelofen. Typologie, Terminologie und Rekonstruktion im deutschsprachigen Raum ( $C H, D, A, F L)$, Schweizer Beiträge zur Kulturgeschichte und Archäologie des Mittelalters 39, Basel 2012.

Sprutta J., Krzyż mistyczny jako Drzewo Życia w sztuce średniowiecznej, „Studia Gnesnensia” 29(2015), s. 329-338.

Strauss K., Die Kachelkunst des 15. und 16. Jahrhunderts in Deutschland, Österreich und der Schweiz, Straßburg 1966.

Tatarkiewicz W., Historia estetyki. Estetyka średniowiecza, Warszawa 1989.

Trojnacka M., Stare druki (XVI-XVIII w.) w zbiorach Biblioteki Uniwersyteckiej KUL. Druki najstarsze, 2004, http://www.bu.kul.pl/art_10847.html [dostęp: 14.09.2017].

Trościński G., Pieśń o Krzyżu i jej nieznany późnośredniowieczny przekaz: z zagadnień polskojęzycznego zasobu literackich pozdrowień Krzyża, „Pamiętnik Literacki” 106/1 (2015), s. 23-44.

Wawrzyniak P., Kafle piecowe w zbiorach bytej Pracowni Naukowo-Badawczej PKZ Sp. z o.o. w Poznaniu, „Wielkopolskie Sprawozdania Archeologiczne” t. 6 (2003), s. 189-217.

Wawrzyniak P., Kafle piecowe z ul. Posadzego na Ostrowie Tumskim w Poznaniu, [w:] Civitas Posnaniensis. Studia z dziejów średniowiecznego Poznania, red. Z. Kurnatowska, T. Jurek, Poznań 2005, s. 407-416.

Wiesiołowski J., Socjotopografia późnośredniowiecznego Poznania, Poznań 1997.

Wojtasik H., Męka Chrystusa w religijności polskiej XVI-XVIII w., [w:] Męka Chrystusa wczoraj i dziś, red. H. Wojtasik, Lublin 1981, s. 61-79.

Ziehr W., Krzyż symbol i rzeczywistość, Warszawa-Kraków 1998.

Zisopulu-Bleja K., Kafle piecowe, [w:] Wyniki badań archeologiczno-architektonicznych przeprowadzonych przy budowie nowej strażnicy na terenie Straży Pożarnej przy ulicy Masztalarskiej 3 w Poznaniu, cz. 1, analiza archeologiczna: 56-67, Poznań 1998 (maszynopis w archiwum Miejskiego Konserwatora Zabytków w Poznaniu).

Zisopulu-Bleja K., Kafle piecowe (XV-XVIII w.), odkryte $w$ trakcie prac archeologicznych $w$ Poznaniu przy ul. Za Bramka (stan. 10, AZP 52-28/157), [w:] Opracowanie wyników archeologicznych badań ratowniczych, prowadzonych w latach 2014-2015, na stanowisku Poznań, Stare Miasto, st. 10, ul. Za Bramka, nr AZP: 52-28/157, red. J. Affelski, Poznań 2015, s. 435-556.

Zuffi S., Nowy Testament. Postacie i epizody, Warszawa 2007. 